\title{
Leptospirosis Surveillance System Readiness in the Banyumas District (A Case Study in the Banyumas District Using a Qualitative Approach, 2015)
}

\section{Nurendah Agung Permatawati}

University of Jenderal Soedirman, Department of Public Health, Purwokerto, Central Java, Indonesia, 53122

\section{Abstract}

Leptospirosis is a newly emerging infectious disease in Indonesia's Banyumas District. Based on data provided by the District Health Office (DHO) in Banyumas, there were 22 cases of leptospirosis between 2010 and May 2014. Leptospirosis surveillance is crucial for the prevention and control of the disease. The aim of

Corresponding Author: Nurendah Agung Permatawati endahpermatawati@gmail.com

Received: 21 January 2018 Accepted: 8 April 2018

Published: 17 May 2018

Publishing services provided by Knowledge $\mathrm{E}$

(c) Nurendah Agung

Permatawati. This article is

distributed under the terms of

the Creative Commons

Attribution License, which permits unrestricted use and redistribution provided that the original author and source are credited.

Selection and Peer-review under the responsibility of the 2nd International Meeting of Public Health 2016 Conference Committee. this study was to achieve an in-depth understanding of leptospirosis surveillance system readiness in the Banyumas District. The research used qualitative methods, and all research data were collected using purposive techniques to examine eight informants via in-depth interviews, observations, and document studies. The data were subject to content analysis. The results showed that input readiness does support the system, but it is inadequate, while overall process readiness was not good enough, and the output was suboptimal. The main supporting factors for this study were the availability of resources, awareness, good communication and research partners/cooperation. The main inhibiting factors were the incomplete nature of the data infrastructure, especially the limited availability of Rapid Diagnstic Tests (RDT) and surveillance case report forms, the lack of reporting agreements, and the lack of evaluating standards. Improvement in and the development of a system with proper budget allocations is required for the availability of microscopic agglutination test (MAT) and polymerase chain reaction (PCR) in hospitals, the development of standard operating procedures (SOP) for the leptospirosis surveillance system, surveillance case report forms, the distribution of RDT at public health centers, and the activation of surveillance based at the community level. With this in mind, it is expected that the DHO Banyumas will create and distribute surveillance case report forms and follow SOP, in order for the leptospirosis surveillance system in Banyumas to be sustained and systematic.

\section{G OPEN ACCESS}




\section{INTRODUCTION}

Leptospirosis is a newly emerging infectious disease in Indonesia's Banyumas District. Data from the District Health Office (DHO) in Banyumas show that there were 22 cases of leptospirosis between 2010 and May 2014. Leptospirosis surveillance is crucial for the prevention and control of the disease.

Based on preliminary survey results from the Banyumas DHO in March 2015, early invention efforts with leptospirosis cases has been suboptimal. To date, the reporting of leptospirosis cases has only been based on telephone reports from the Banyumas and Margono Hospitals. The lack of a good leptospirosis surveillance system has made it impossible to determine the true number of leptospirosis cases in Indonesia. Leptospirosis is a public health problem with a considerable spread, and the recorded incidence rate of the disease has been increasing in countries with good surveillance systems [7].

Anwar (2010) supports the above assessment of the current situation and argues that the implementation of a surveillance program can be carried out well if the program is built from a good system. Such a "good system" can be established by input, process, and output protocols. The aim of this study was to achieve an in-depth understanding of the leptospirosis surveillance system readiness in the Banyumas District. Then, the research can be used to improve and develop a more effective leptospirosis surveillance system for the Banyumas District.

\section{METHODS}

The research used qualitative methods wherein data were collected via purposive techniques from eight informants. All informants were selected for participation in this study based on their compatibility and the sufficiency principle, and data were collected from in-depth interviews, observations and document studies.

All data were subject to content analysis. Then, set issues were analyzed through the coding process. Codes were grouped with a thematic approach to be basic theme, developed theme and global theme until the data were more structured.

\section{RESULTS}

\subsection{Overview of Informants}


TABLE 1: Description of Informants.

\begin{tabular}{|c|c|c|c|}
\hline Informant Code & Age/ Gender & Occupation/ Position & Degree of Education \\
\hline A.1 & 54 / Female & $\begin{array}{l}\text { DKK Banyumas/ Head of } \\
\text { P2PL Fields }\end{array}$ & Graduate degree \\
\hline A. 2 & 48 / Male & $\begin{array}{l}\text { DKK Banyumas/ Head of } \\
\text { Diseases Control Section }\end{array}$ & Graduate degree \\
\hline A. 3 & 48 / Male & $\begin{array}{l}\text { DKK Banyumas/ } \\
\text { Leptospirosis Programmer }\end{array}$ & $\begin{array}{l}\text { Undergraduate/ } \\
\text { Epidemiology }\end{array}$ \\
\hline B.1 & 36 / Male & $\begin{array}{l}\text { Banyumas Hospital/ } \\
\text { Medical Record Staff }\end{array}$ & $\begin{array}{l}\text { Undergraduate/ Medical } \\
\text { Records }\end{array}$ \\
\hline B.2 & 43 / Male & Banyumas Hospital/ Nurse & Associate's degree/ Nurse \\
\hline C.1 & 36 / Female & $\begin{array}{l}\text { Puskesmas } 1 \text { Kemranjen/ } \\
\text { Surveillance Staff }\end{array}$ & $\begin{array}{l}\text { Undergraduate/ Health } \\
\text { Promotion }\end{array}$ \\
\hline D.1 & 27 / Female & $\begin{array}{l}\text { Puskesmas } 2 \text { Sumpiuh/ } \\
\text { Surveillance Staff }\end{array}$ & $\begin{array}{l}\text { Undergraduate/ } \\
\text { Epidemiology }\end{array}$ \\
\hline D.2 & 33 / Male & $\begin{array}{l}\text { Puskesmas } 2 \text { Sumpiuh/ } \\
\text { Doctor }\end{array}$ & Undergraduate/ Doctor \\
\hline
\end{tabular}

\subsection{Input Readiness of Leptospirosis Surveillance System in the Banyumas District}

The Banyumas District had adequate and prepared personnel for the implementation of a leptospirosis surveillance system. It consists of personnel at the district level and at public health centers with integration task excessive.

"...Actually, I was ready, but sometimes I have integration task too much, so less covered. Many programs must be completed. Myself as a promoter, manage alert village, routine counseling. Generally, surveillance staff in Banyumas District have integration task among as surveillance staff, environmental health staff and health promoter..." (C.1)

The Banyumas District has some funding allocated for leptospirosis surveillance, but it was limited to supplying rapid diagnostic tests (RDTs). In addition, the district has support facilities available for a leptospirosis surveillance system, but it is incomplete. It consists of RDTs at a public health center, polymerase chain reaction (PCR) and microscopic agglutination test (MAT), and the tabulation of data with appropriate software. However, the distribution of RDTs among hospitals is uneven, and leptospirosis case report forms are not available.

"Yes, the lack of form, the form should have been prepared for reporting" (B.2). 


\subsection{Process Readiness of Leptospirosis Surveillance System in the Banyumas District}

The health office and public health center had prepared and made plans for the implementation of a leptospirosis surveillance system consisting of budgeting and program planning. Data were collected by passive surveillance and reporting was done on a case-by-case basis. Each case was followed up by an epidemiology investigation, elucidation, and spot survey rodent.

"Surveillance system in health office has appropriate procedures and keep working with public health center, public health center follow-up that case, epidemiological investigation, educate to community, health office follows up with field surveys and spot survey rodent. When conducting surveys, involving the community." (C.1)

Data management at the district level has three directions for the dissemination of information. Monitoring is done in stages, and evaluation consists of supervision and reviews. No evaluation standards were available.

"In conducting evaluations, we held a review, invite surveillance staff in public health center in Banyumas District to discuss cases that have occurred. We don't have a standard evaluation" (A.3)

\subsection{Output of the Leptospirosis Surveillance System in the Banyumas District was Suboptimal}

Interventions in leptospirosis cases in the Banyumas District are not optimal because many of them go unreported. Until now, the reporting of cases from hospitals and case inventions at public health centers has not been optimal.

"Yes, it was not optimal, actually those cases have been existed before but unreported" (A.1)

\subsection{Supporting and Inhibiting Factors of the Leptospirosis Surveillance System in the Banyumas District}

Support for the system can manifest in terms of follow-up and the dissemination of information, awareness by reporters, partnerships/cooperation, good communication, 
and input readiness. Meanwhile, the main factors that inhibit the system are a lack of personnel knowledge about leptospirosis and the ambiguity of the reporting system.

"I don't know, because up till now there is ambiguity of reporting system" (B.2)

\subsection{Improvements and Development of the Leptospirosis Surveillance System in the Banyumas District}

The leptospirosis surveillance system in the Banyumas District can be improved and developed by activating a surveillance system based on community involvement, the distribution of RDTs to public health centers, the creation of standard operating procedures (SOP), a leptospirosis case report form, and the refreshing of surveillance staff knowledge.

\section{DISCUSSION}

According to Report 45 by Indonesia's Minister of Health from 2014, "The Implementation of Health Surveillance" must be supported with the availability of human resources who have competence in the field of epidemiology, adequate budgeting, and facilities. Personnel at district and public health centers were available, but the integration tasks assigned to them were excessive. Nevertheless, integration tasks should not be an obstacle to the system. What should be prepared is a plan for how to establish a surveillance staff. One of the ways to do this is through training (refreshing). Prasastin (2013) explained that the participation of staff in repetitive training will make them more capable of understanding the information provided to them and increases their comprehension and knowledge of the subject.

The lack of a leptospirosis case reporting form at hospitals was presumed to be due to the low number of leptospirosis cases reported since 2010 in the Banyumas District. The availability of this form can influence the completeness of data related to the disease and help to create a systematic plan to track it. According by Khayati (2012), the completeness of data is crucial for observing the development of cases. An availability of data leads to better resources for information. The reporting system must also have a high degree of completeness, so that that it can serve as evidence for policy interpretation [3].

Some steps of the implementation process had not been done to suit the needed procedures. The lack of a case report form and the ambiguity of the reporting system during the data collection steps are particularly troubling. Therefore, developing an SOP 


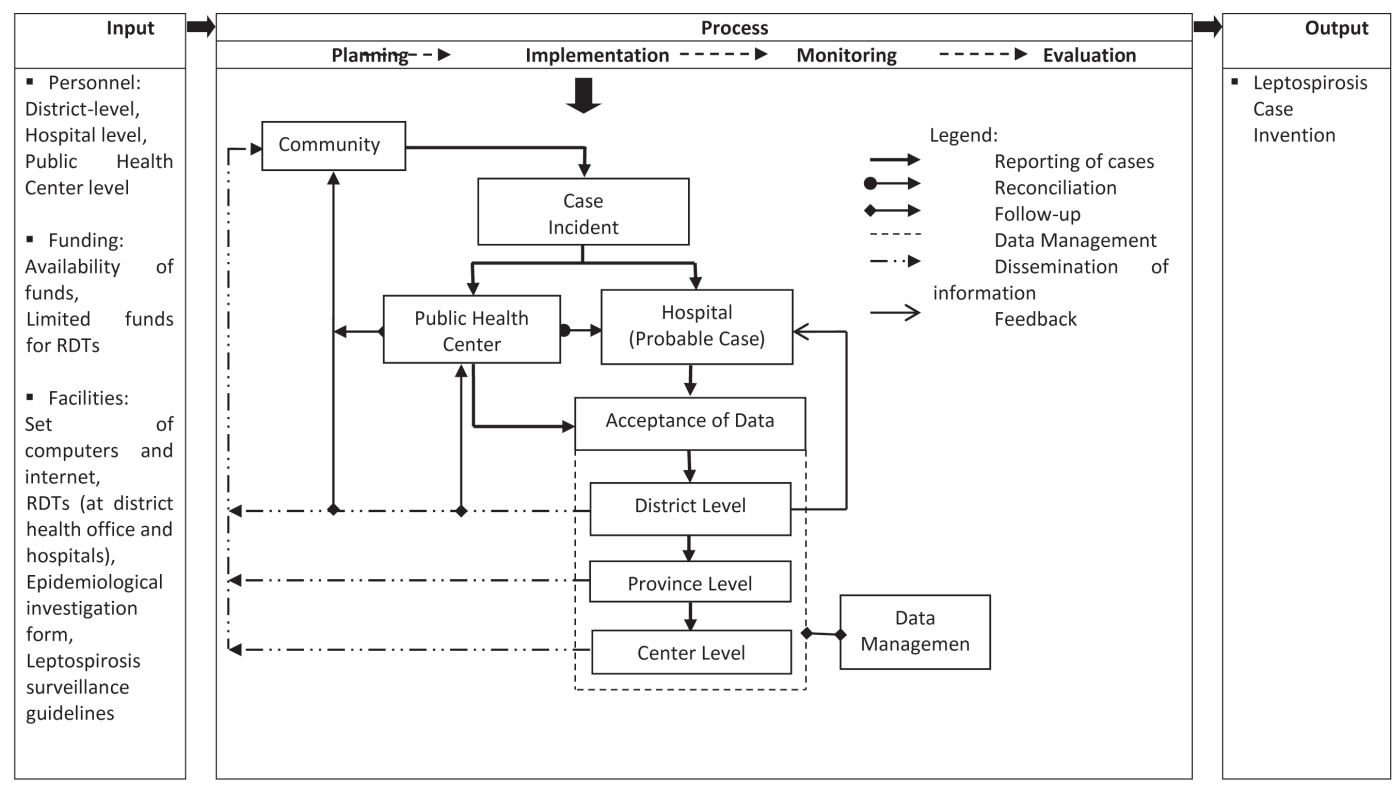

Figure 1: Flow Chart of the Leptospirosis Surveillance System in the Banyumas District.

is required for reporting agreements. In addition, monitoring and evaluation efforts were suboptimal because of the lack of an evaluation standard as an indicator of surveillance performance. With this in mind, a new evaluation standard is required to understand the achievements and success indicators of the leptospirosis surveillance system, and so authorities can determine the strategies and plans for upcoming years.

Based on the results of this study, leptospirosis is not a familiar condition in the Banyumas District. Leptospirosis cases were reported too often from one hospital in the Banyumas District Area. Sunaryo (2014), in his study, explained that leptospirosis cases in the Gresik District were also over-reported by the hospital in that area. Further, the limited availability of facilities, particularly RDTs and laboratory equipment, in public health centers is of concern. Yunianto (2009) proved that, by doing a case crawl through the distribution of leptospirosis detection equipment in public health centers, we can help find suspects in the community.

\section{CONCLUSION}

The leptospirosis surveillance system in the Banyumas District had some input readiness that supported the system, but it was inadequate. The process readiness was not good enough, and output was suboptimal. Input and process readiness have an impact on the program's output success, so improvement and further development are required. 


\section{References}

[1] Anwar, Azrul. 2010. Introduction of Health Administration. Binarupa Aksara Publisher : Tangerang.

[2] Khayati, N., Yuliawati, S., \& Wuryanto, M. 2012. Officers Factors Related to Implementation of Malaria Epidemiologic Surveillance at The Public Health Center in Purworejo District. Journal of Public Health 1(2), 364-373.

[3] Natalia, A. 2012. Overview of Epidemiological Surveillance of Dengue Fever from The Staff's Aspect at Public Health Center in Semarang. Journal of Public Health 1(2), 262-271.

[4] Permenkes RI. 2014. Regulation of Health Minister of Republic Indonesia Number 45, 2014 About Implementation of Health Surveillance.

[5] Prasastin, O.V. 2013. Factors Related to Performance of Malaria Epidemiological Surveillance Officers at The Public Health Center in Kebumen District in 2012. Unnes Journal of Public Health 2(4).

[6] Sunaryo dan Dewi Puspita Ningsih. 2014. Spatial Distribution of Leptospirosis in Gresik District, East Java. Health Research Bulletin Volume 42, Number 3: 161-170.

[7] Vijayachari P, Sugunan AP, Shiram AN. 2008. Leptospirosis: an Emerging Global Public Health Problem. J. Biosci 33(4). Pp 557-569.

[8] Yunianto B, IH Nur, W Diah, Sunaryo. 2009. Epidemiological Study of Leptospirosis in Semarang, Central Java in 2008. http: //www . lokabanjarnegara. litbang. depkes . go.id/penelitians/view/33 